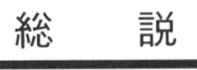

\title{
健康の維持と油脂の至適掑取量： 脂肪酸の掑取バランスを中心に
}

\author{
辻悦子 \\ 川崎医療福祉大学 医療技術学部健康体育学科 \\ （テ701-0193 岡山県倉敷市松島 288）
}

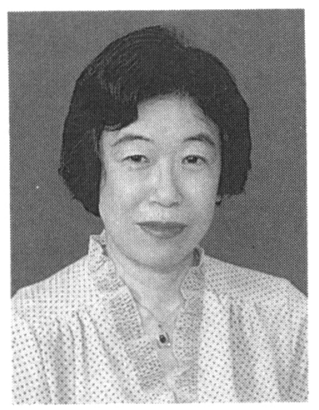

\section{Dietary Fat Intake for Maintaining Health}

\author{
Etsuko TsuJI \\ Department of Health and Sports Sciences, Faculty of Medical Professions \\ Kawasaki University of Medical Welfare \\ (288, Matsushima, Kurashiki-shi, Okayama-ken 701-0193)
}

\begin{abstract}
Dietary fats and oils are essential for maintaining health. The chemical characteristics and physiological effects of fats and oils differ. And the various fatty acids present in fats and oils have different functions in human nutrition, and thus a well-balanced intake is desirable. Not only the quantity of fat but also the quality of fat or fatty acids are recommended for maintaining good health in the Recommended Dietary Allowances for Japanese.

In 1946 daily average intake of dietary fat by Japanese was $14.7 \mathrm{~g}$, and fat energy ratio was $7.0 \%$. By 1997, the intake of fat had increased to $59.3 \mathrm{~g}$, with cooking fats and oils accounting for $17.0 \mathrm{~g}$. The increase in fat intake was due not only to vegetable oil consumption but much more so to a marked increase in dietary animal fat.

Yearly changes in fatty acid intake from 1952 through 1997 by Japanese were determined based on the National Nutrition Survey. The $n-6 / n-3$ and other fatty acid intake data were calculated.

The relation between colon and breast cancer mortality and dietary fatty acid intake was discussed. A significant increase in mortality was found with increased fat intake, and it is suggested that as a preventive measure fat intake should not exceed designated levels.
\end{abstract}

Key words : dietary fats and oils, fatty acid intake, n-6/n-3 ratio, recommemded dietary allowances for Japanese, maintaining health

\section{1 はじめに}

脂肪（脂質）の椇取はエネルギー源として重要である のみならず，身体の機能維持のために必要な必須脂肪酸 や脂溶性物質を供給するなどの生理機能を有するために 必要である11.22。年のために我々は食用油脂を掑取する が, 油脂の主成分は中性脂肪（トリアシルグリセリン） である。その油脂の栄養学的機能は中性脂肪を構成する 脂肪酸の種類により決まると言えよう。なお，食品成分 表では脂質，栄藓調查では脂肪と言うように食品や栄養 の分野では両者を同義語として用いている。

そこで, 健康維持のための至適な油脂掑取量を考光る
には，我々のいままでの掑取脂肪量や，国民のために国 がとってきた行政施策を知ることは重要なことである。 その上で, 油脂を構成する脂肪酸量やそのバランスと疾 病との関連を検討しながら述べる。

\section{2 日本人の脂肪摂取量}

まず，これまでの日本人の脂肪㩧取量の推移を各種の 調査からたどってみる。

$2 \cdot 1$ 戦前, 戦時下の脂肪摂取量

戦前の栄養攝取と食糧消費状況についての資料は少な

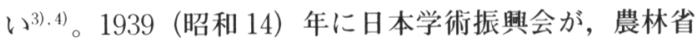
の資料をもとに国民食糧の現状を発表し, 1911 (明治 44) 
年から 1915 (大正 4) 年, 1921 (大正 10) 年から 1925 (大 正 14）年, 1931 (昭和 6) 年から 1935 （昭和 10）年に わたる食品消費状況を調查している。それによると, 全 国平均 1 人 1 日当たり脂肪攝取量は 1911〜1915 年が $13.1 \mathrm{~g}, 1921 \sim 1925$ 年が $16.5 \mathrm{~g}$ であり, 脂肪エネルギー 比を計算してみるとそれぞれ，5.6\%，6.4\%であった。 タンパク質は総エネルギーの約 11〜 12\%, 炭水化物は 80\%を越えていた。

戦時下では労働科学研究所が工場給食の栄養調查を $1941 （$ 昭和 16）年から $1947 （$ 昭和 22）年まで行ってい るが，脂肪給与量は $21 \sim 15 \mathrm{~g}$ であった。

\section{$2 \cdot 2$ 戦後の脂肪攝取量}

第 2 次世界大戦終結後のわが国は著しい食糧不足状態 であり，これを解消するため食糧援助を受ける必要にせ まられた。そのための基礎資料を作成する目的で，東京 都民 3500 世帯約 3 万人を対象に栄養調査が実施された (1945 年)。これが現在厚生省が毎年行っている国民栄 養調查の始まりである。

1946 年には，年間平均で脂肪摂取量は $14.7 \mathrm{~g}$ ，脂肪 エネルギー比に換算すると $7.0 \%$ であり, 油脂類の捸取 はわずか $1.7 \mathrm{~g}$ であった。1952 年には栄養改善法が制定 されたのに伴い，国民の栄養改善を目的として国民栄養 調査が行われている。食糧確保の目的から，健全な国民 の健康の確保, 青少年の体位・体力向上をめざし, さら に国民の健康維持・増進を図ることを目的とするなど， それぞれの時代の栄養・食糧事情を反映するものとし て，国民栄養調查の果たす役割は重要なものである。

Table 1 に国民栄養調查から脂肪攝取量の年次変化の 一部を示した。なおこの調查は 1995 年から調查対象が 世帯から個人に切り替わっている。1997（平成 9) 年の

Table 1 Yearly Changes in Fat Intake.

\begin{tabular}{l|cc}
\hline \multicolumn{2}{c}{ Fat(g) } & Fat Energy Ratio(\%) \\
\hline 1946 & 14.7 & 7.0 \\
1952 & 20.1 & 8.6 \\
1955 & 20.3 & 8.7 \\
1960 & 24.7 & 10.6 \\
1965 & 36.0 & 14.8 \\
1970 & 46.5 & 18.9 \\
1973 & 52.2 & 20.7 \\
1975 & 52.0 & 21.4 \\
1980 & 55.6 & 23.6 \\
1985 & 56.9 & 24.5 \\
1988 & 58.3 & 25.5 \\
1989 & 58.9 & 25.7 \\
1993 & 58.1 & 25.7 \\
1995 & 59.9 & 26.4 \\
1996 & 58.9 & 26.5 \\
1997 & 59.3 & 26.6 \\
\hline
\end{tabular}

(Ministry of Health and Welfare)
調査 ${ }^{5)}$ では脂肪攝取量は $59.3 \mathrm{~g}$, 脂肪エネルギー比は $26.6 \%$ であった。1952 年の脂肪椇取量 $20.1 \mathrm{~g}$, 脂肪工 ネルギー比 $8.6 \%$ に比べると約 3 倍に増加している。こ の脂肪エネルギー比は 1973 年には $20.7 \% ， 1988$ 年には $25.5 \%$ に達し，栄養所要量で適正とされている上限の $25 \%$ を超えている。このため, 脂肪の椇取は過剩であ るとの警告がなされたにもかかわらず，25\%を超えた 状態が依然として続いている。これは，1955（昭利 30） 年頃から始まった経済成長に伴い, 所得が増加し, 消費 革命も見られ, 食生活の洋風化, 多様化の現象の中で, 肉類, 卵類, 乳類などの畜産食品や油脂類の掑取が著し く伸びたことに依るものである。脂肪の増加に対し，米 類や雑穀類の減少により炭水化物の摄取は減少してきて いる。

この脂肪の攝取量には個人差が大きい上，世帯業態で みると非農家世帯（自営業，常用勤労者，日雇労働者な ど)では,農家世帯に比べ適正上限の $25 \%$ を超えるうえ， 質的にも動物性／植物性脂肪比が高くなっている。また 人口規模でみると，人口の少ない市・町村より人口の多 い都市で，支出階層別に見ると 1 人 1 ヶ月当たりの家計 上の現金支出額の少ない世帯より多い世帯で，脂肪掑取 量や動物性／植物性脂肪比が高いというように格差がか なり見られる。Fig. 1 に 1995 年の栄養素別エネルギー 構成比を示すが，脂肪エネルギー比は加龄とともに低下 し，20〜40歳代では適正比率を超えていた。子供達( 青少年 ${ }^{7}$ でも量的に適正範囲を超える傾向が強く，動物 性脂肪の摄取割合も多くなっている。このような現状で は高脂血症など生活習慣病予防の観点から注意を払う必 要がある。

\section{$2 \cdot 3$ 脂質供給源の変遷}

国民栄養調査から脂質供給源の推移（Fig. 2）をみる と, 1952 年では穀類, 豆類, 油脂類, 魚介類の順で压 倒的に植物性食品が優位を占め, 動物性（含魚類）：植 物性脂肪 $=1: 2.4$ 〔ただし，魚類由来の脂肪を植物性脂

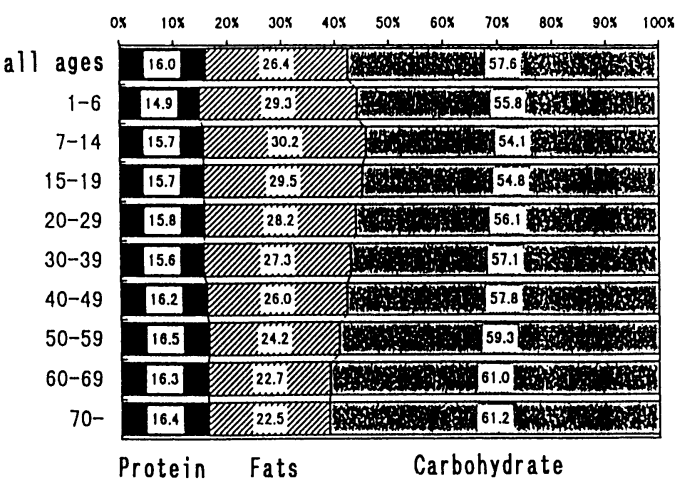

Fig. 1 Nutrient Energy Ratio in Japan by Age. (Ministry of Health and Welfare, 1995) 


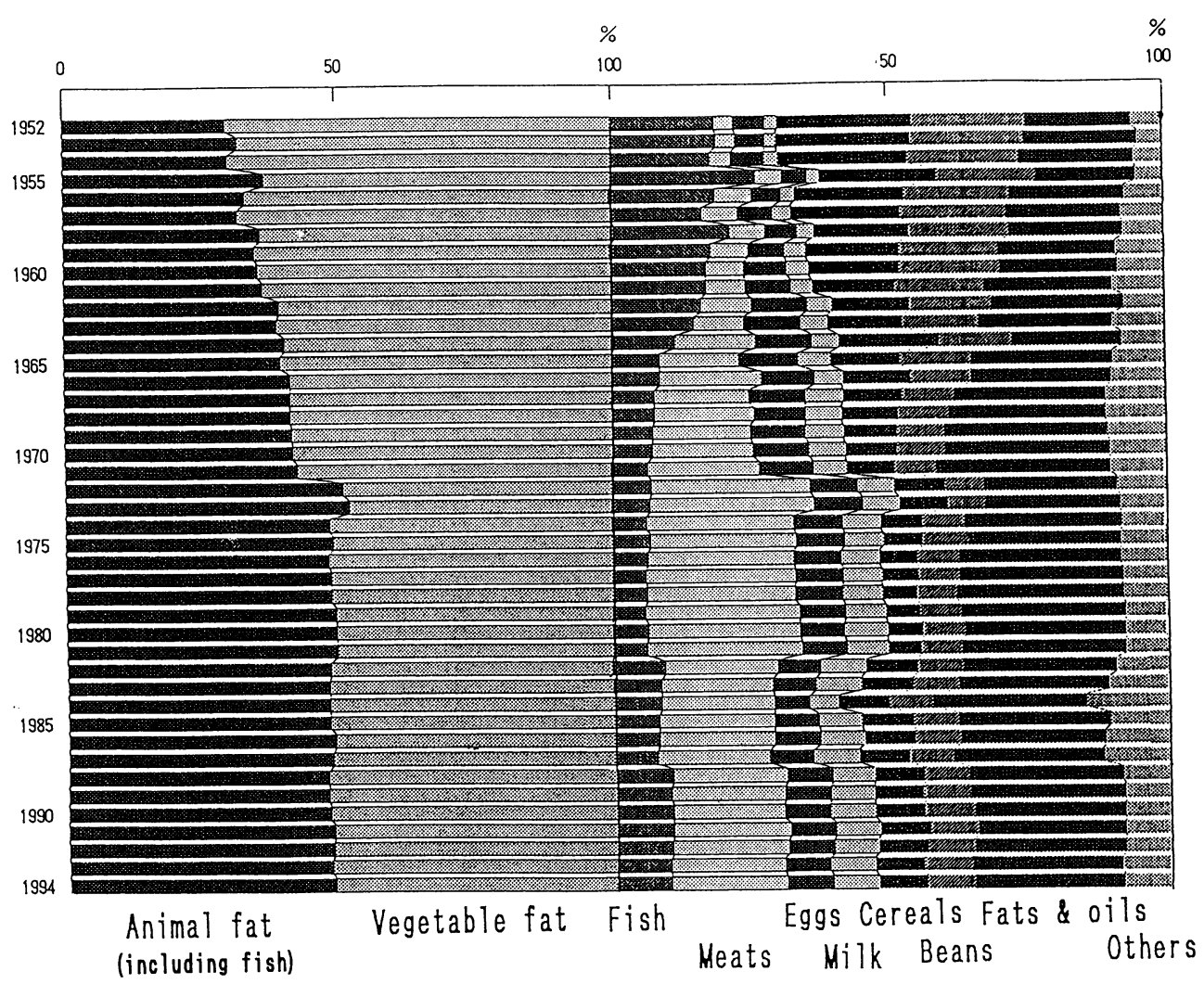

Fig. 2 Changes in Fat Intake Ratio from Various Food Sources in Japan.

(National Nutrition Survey)

肪に含めると, 動物性：植物性 (含魚類 $)=1: 7.8$ とな る]，動物性：植物性：魚類脂肪=0.6:3.7:1 であっ た。脂肪エネルギー比が $20 \%$ になった 1973 年には，獣 鳥肉類が首位で, 油脂類, 殼類, 卵類と続き, 動物性 (含 魚類)：植物性脂肪=1 :0.9〔同じく,動物性：植物性(含 魚類 $)=1: 1.1]$, 動物性：植物性：魚類脂肪=6.4:6.7 $: 1$ と動物性脂肪, しかも獣鳥肉類からの捸取量が著し く増加した。脂肪エネルギー比が 25\%を超えた 1988 年 では, 油脂類が首位, ついで獣鳥肉類, 魚介類で, 穀類 からの寄与率は相変わらず低かった。動物性（含魚類） : 植物性脂肪 $=1: 1.1$ 〔同じく, 動物性：植物性（含魚 類 $)=1: 1.7$, 動物性 : 植物性 : 魚類脂肪=3.6:4.7: 1 となっている。なお，油脂類については，1955年まで

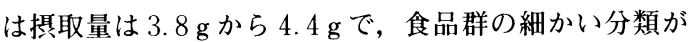
なされていないので不明であるが, 当時バタ一, 、ヨネ一 ズ，マーガリンの消費が大きいとは考えにくく，ほとん どが植物性油脂と考える方が妥当と思われる。1956 年 からは油脂類の中に植物油という分類が記載され, 植物 油摂取量は $3.8 \mathrm{~g}$ で当時は油脂類 $(4.6 \mathrm{~g})$ の約 8 割を占 めていた。現在では油脂類中の植物油の占める割合は約 6 割である（1995 年は油脂類 $15.1 \mathrm{~g}$ 中植物油の攝取量
は $9.4 \mathrm{~g})$ 。このように, 油脂類の攝取は量的には 4 倍程 度増加してきたが，脂肪全体に占める割合から見れば 1952 年の $19 \%$ から最近ではほぼ $27 \%$ という増加であ る。1995 年の結果によれば, 油脂類が首位で, 獣鳥肉類, 魚介類の順で, 動物性：植物性 (含魚類 $)=1: 1.6$, 動 物性：植物性：魚類脂肪 $=4.2: 5.2: 1$ となり, 1997 年 は同じく $3.9: 4.8: 1$ で最近の約 10 年は動物性：植物 性：魚類由来の脂肪は，ほぼ $4: 5: 1$ と栄養所要量に記 載されている比率であることがわかる。しかしいずれに しても, 植物性食品由来の脂肪摂取が減少し, 動物性食 品由来の脂肪摂取が明らかに増加してきたことは間違い ない。

\section{3 日本人の脂肪酸摂取量}

ところで, 脂肪酸はその化学構造の違いによりそれぞ れ生理機能を異にしている。そのため，どのような割合 で掑取するのがよいのかということが議論の的とされる ところである。

\section{$3 \cdot 1$ 脂肪酸摂取量とその比率}

食品中の脂肪酸, コレステロールやビタミン $\mathrm{E}$ 等の 脂溶性成分の含量がまとめられる前に，筆者は日本人の 


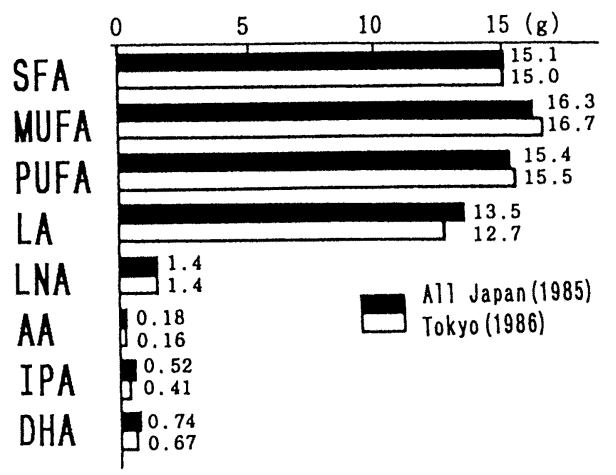

Fig. 3 Fatty Acid Intake in Japan.

SFA : Saturated fatty acid, MUFA : Monounsaturated fatty acid, PUFA : Polyunsaturated fatty acid, LA : Linoleic acid, LNA : $\alpha$-Linolenic acid, AA : Arachidonic acid, IPA : Icosapentaenoic acid, DHA : Docosahexaenoic acid

脂肪酸の摂取量に関して，国民栄養調查および東京都民 栄養調查の成績から試算してみた ${ }^{8)}($ Fig. 3)。n-6 系脂 肪酸としてリノール酸, アラキドン酸を, $\mathrm{n}-3$ 系脂肪酸 として $\alpha^{-リ}$ リレン酸，イコサペンタエン酸，ドコサへ キサエン酸を用いて算出した $\mathrm{n}-6 / \mathrm{n}-3$ 比は 5.1 , リノー ル酸/ $\alpha$-リノレン酸比は 9.6 であった。その後，脂肪酸 捸取量を算出する多くの試みがなされているが，吉田 ${ }^{9)}$, 辻 ${ }^{10)}$ は n-6/n-3 比は 3.6 , 平原 ${ }^{11)}$ は 1971 年から 20 年間 の平均値として 4.2 と報告している。これらの成績から， 日本人の n-6/n-3 比はほぼ 4 5 という数值が示された。

\section{$3 \cdot 2$ 脂肪酸摂取量の長期間推移}

そこで 1952 年から 1995 年までの 44 年間の長期にわ たる脂肪酸摂取量を国民栄養調査結果から算出した ${ }^{12)}$ 。 各食品群中の脂肪酸量は日本食品脂溶性成分表 ${ }^{13)}$ にある 食品の数值の平均を用いた。なお，40 年前の食品と現 在の食品では，その成分值に違いがあるのはいうまでも ないが，すべて，現在の食品とみなして計算した。

その結果をまとめて Fig. 4 に示す。脂肪総椇取量や 動物性脂肪については，前にも述べたように増加が著し い。このことは，椇取される脂肪酸の量にも影響し，総 脂肪酸捸取量も増加した。これに伴い，飽和脂肪酸 $(\mathrm{S})$ のみならず，一価不飽和脂肪酸 ( $\mathrm{M})$, 多価不飽和脂肪 酸（P）も顕著に増加した。1995 年では，S $16.5 \mathrm{~g} ， \mathrm{M}$ $18.5 \mathrm{~g}, \mathrm{P} 14.9 \mathrm{~g}$ であり, 1952 年の $\mathrm{S} 4.7 \mathrm{~g}, \mathrm{M} 4.7 \mathrm{~g}$, $\mathrm{P} 6.9 \mathrm{~g}$ と比較すると, $\mathrm{S} ： \mathrm{M} ： \mathrm{P}$ は 1952 年の $1 ： 1$ : 1.5 から 1995 年には $1 ： 1.1 ： 1$ と変化した。1995 年の $\mathrm{n}-6$ 系 $\mathrm{P}$ はリノール酸 $11.8 \mathrm{~g}$, アラキドン酸 $0.3 \mathrm{~g}$ で総 量としては $12.3 \mathrm{~g}, \mathrm{n}-3$ 系 $\mathrm{P}$ は $\alpha$-リノレン酸 $1.4 \mathrm{~g}$, ド コサヘキサエン酸 $0.7 \mathrm{~g}$ ，イコサペンタエン酸 $0.4 \mathrm{~g}$ で 総量としては $2.6 \mathrm{~g}$ であった。これから求めた $\mathrm{n}-6 / \mathrm{n}-3$

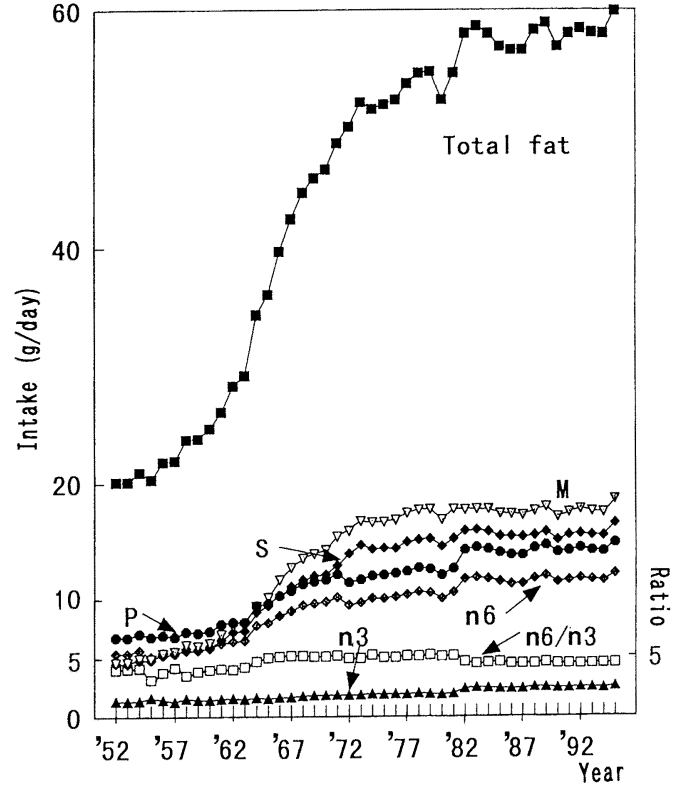

Fig. 4 Changes in Daily Fat and Fatty Acid Intake and Its Ratio.

S : Saturated fatty acid. M : Monounsaturated fatty acid, P : Polyunsaturated fatty acid, n $6: \mathrm{n}$ 6 Polyunsaturated fatty acid, n $3:$ n-3 Polyunsaturated fatty acid

比は 4.7 , リノール酸/ $\alpha$-リノレン酸比は 8.8 となった。 1952 年では $n-6 / n-3$ 比は 4.1 , リノール酸/ $\alpha$-リノレン 酸比は 8.6 であった。n-6/n-3 比は 1965 年頃から 5 を 超えその傾向はしばらく続いた後低下し，最近の 10 数 年は近似した值で，44 年間では 4 5 の值で推移してい た。また，n-6 系をリノール酸・アラキドン酸に, n-3 系を $\alpha$-リノレン酸・ドコサヘキサエン酸・イコサペン タエン酸に限って算出した $\mathrm{n}-6 / \mathrm{n}-3$ 比は 5.0 となり，前 に示した 1985 年の值 5.1 と近い值であった。これらの ことから, 脂肪酸摃取量は 2〜4倍に増えてはいるもの の, 脂肪酸の比率そのものは，この数十年間若干の増減 はあるが，驚くほどの変化は無いことが判明した。すな わち，日本人の摂取している $\mathrm{P} の \mathrm{n}-6 / \mathrm{n}-3$ 比は，所要 量で厚生省が示している目安の值に近い值であったので ある。

もっとも，摄取される脂肪酸の総量は，1952年の $16.3 \mathrm{~g}$ から，1973 年には $43.1 \mathrm{~g}, 1988$ 年には $47.4 \mathrm{~g}$, そして 1995 年には $49.9 \mathrm{~g}$ とめざましい増加を見せてい る。そしてこの脂肪酸のうち，量的には増えているもの の, リメール酸の総脂肪酸量に占める割合は 1952 年の 約 33\% から，それぞれ 22\%，24\%，24\% と相対的な割 合はむしろ減少してきている。これに対し M P S の増 加は著しく， S は 1995 年では 1952 年の 3.5 倍もの伸び 
であった。それに比べると，P の増加は 2.3 倍にとどま り, 総脂肪酸量の増加は動物性脂肪や油脂類等の S P Mに起因すると考えられる。このような現象が， n-6 や n-3 系 P の量は増えたにもかかわらずその比率に大きな 影響を与えないことの原因の一つでもあろう。なお， 44 年の間には食品成分表の改訂があったことから，その影 響も考慮する必要があろう。

さらに 1996 年では S $15.8 \mathrm{~g}, \mathrm{M} 17.8 \mathrm{~g}, \mathrm{P} 14.3 \mathrm{~g}$, $\mathrm{n}-6 / \mathrm{n}-3$ 比 4.6 , リノール酸/ $\alpha$-リノレン酸比 8.7 に, 1997 年では S $15.8 \mathrm{~g}, \mathrm{M} 17.9 \mathrm{~g}, \mathrm{P} 14.3 \mathrm{~g}, \mathrm{n}-6 / \mathrm{n}-3$ 比 4.5 ，リノール酸 $/ \alpha$-リノレン酸比 8.7 と僅かではある が変化し, 脂肪酸の内訳としては n-6 系 $\mathrm{P}$ 特にリノー ル酸摂取量（1996・1997 年とも $11.3 \mathrm{~g} ）$ の減少傾向が 見られた。これは食品群で植物油椇取の減少と魚類の攝 取増加が影響しているようであり，この数年間の普及啓 蒙活動の効果とも思われ, n-6/n-3 比の改善のためには 好ましい傾向と考えられる。

これらの $\mathrm{n}-6 \cdot \mathrm{n}-3$ 系 $\mathrm{P}$ を供給している食品群は, 次 のようである。n-6 系では油脂類が $42 \%$ で 1 位, 以下 豆類，穀類と続き，n-3 系では魚類が 44\%の 1 位で, 油脂類, 豆類と続き, 両系列とも3位までの食品が脂肪 酸の約 8 割を占めていた。このことからもわかるように, これまでわが国では動物性食品の摂取が増え，それに伴 う動物性脂肪の量が増加してきたが, n-6 や $\mathrm{n}-3$ 系 $\mathrm{P}$ 量 の供給に対する動物性食品の寄与率は小さいものであっ た。

しかし，n-6 系，n-3 系ともに，食品としては油脂類 がこれら Pの主たる供給源になっていることは明らか
である。

\section{4 油脂類の脂肪酸}

\section{$4 \cdot 1$ 植物油の脂肪酸組成}

油脂類としては, 植物油, 動物性油脂, バター, マー ガリン，マヨネーズ類があるが，なかでも植物油が油脂 類撕取量の約 6 割を占めている。Fig. 5 に植物油の脂 肪酸組成を示した。

植物油の中でも，ヤシ油やパーム油は S が，オリブ 油やなたね油は $\mathrm{M}$ が，サフラワー油やえごま油，ひま わり油, 大豆油には $\mathrm{P}$ が多く, その中でも, サフラワー 油はリノール酸，えごま油は $\alpha$-リノレン酸含量が多い。

Table 2 に植物油中の $\mathrm{P}$ 含有量を示す。

\section{$4 \cdot 2$ 捸取植物油を置換した時の脂肪酸比率}

われわれは，日常の食事で単品だけを食べることは少 ない。また，日本国民全てが同じ食品や油脂類をとって いるわけではない。しかし，油脂の攝取バランスを考え る上では，食品を一定のものに仮定して作業することに も大きな意義があると思われる。

1994 年度の結果 $(\mathrm{n}-6 / \mathrm{n}-3=4.66$, リノール酸 $/ \alpha-$ リ ノレン酸 $=8.97$ ）を基にして, 油脂類中の植物油以外の 食品とそれに含まれる脂肪掑取量はそのままにして, 植 物油を Table 2 の各植物油単品だけを使用したと仮定し て脂肪酸比率を算出してみた（Table 3)。仮に，サフラ ワー油を使用するとすれば，n-6/n-3 比は 6.9 であり， この比率を 4 に近似させようとすると，なたね油を混合 してある調合油を用いるとちょうど 4 になった。一方， $\alpha$-リノレン酸の多いえごま油では n-6/n-3 比は著しく

Safflower oil

Perilla oil

Sunflower oil

Soybean oil

Cotton seed oil

Blended oil

Corn oil

Sesame oil

Blended salad oil

Rice bran oil

Peanut oil

Rape seed oil

olive oil

Palm oil

Palm kernel oil

Coconut oil

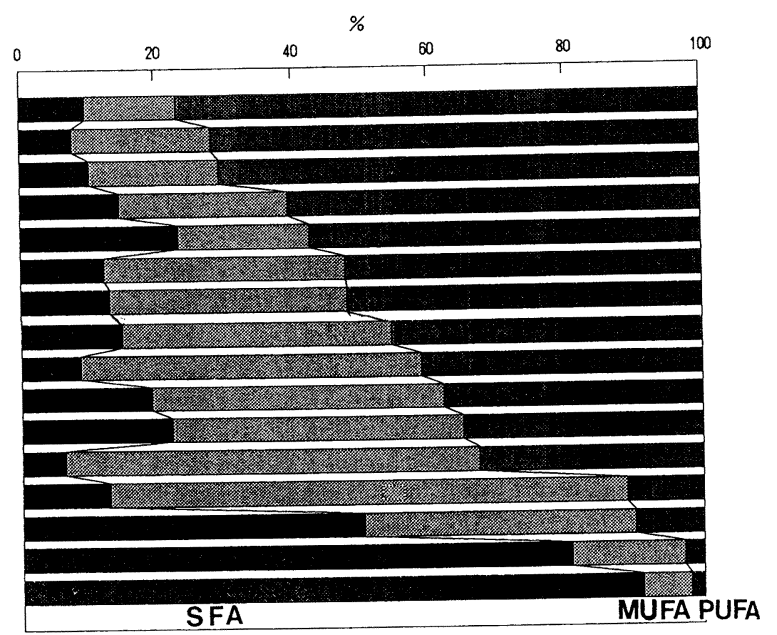

Fig. 5 Fatty Acid Composition in Vegetable Oils.

Blended salad oil= Rape seed oil 7 : Soybean oil 3, Blended oil=Rape seed oil 3 : Soybean oil 7, SFA : Saturated fatty acid, MUFA : Monounsaturated fatty acid, PUFA : Polyunsaturated fatty acid

(Food Composition Table et al.) 
Table 2 Contents of n-6, n-3 Fatty Acid and Fatty Acid Ratio in Oils.

\begin{tabular}{lccc}
\hline \multicolumn{1}{c}{ Oils } & $\mathrm{n} 6 \mathrm{mg} / \mathrm{g}$ & $\mathrm{n} 3 \mathrm{mg} / \mathrm{g}$ & $\mathrm{n} 6 / \mathrm{n} 3$ \\
\hline Perilla oil & 140 & 570 & 0.2 \\
Rape seed oil & 218 & 108 & 2.0 \\
Blended Salad oil & 312 & 99 & 3.2 \\
Blended oil & 434 & 88 & 4.9 \\
Soybean oil & 527 & 79 & 6.7 \\
Olive oil & 104 & 8 & 13.0 \\
Rice bran oil & 366 & 14 & 26.1 \\
Corn oil & 505 & 15 & 33.7 \\
Sesame oil & 448 & 6 & 74.7 \\
Sunflower oil & 699 & 7 & 99.9 \\
Cotton seed oil & 569 & 5 & 113.8 \\
Peanut oil & 349 & 2 & 174.5 \\
Safflower oil & 764 & 2 & 382.0 \\
Palm kernel oil & 27 & 2 & 13.5 \\
Palm oil & 96 & 3 & 32.0 \\
Coconut oil & 20 & 0 & - \\
\hline
\end{tabular}

Blended salad oil $=$ Rape seed oil $7:$ Soybean oil 3 Blended oil $=$ Rape seed oil 3 : Soybean oil 7

(Food Composition Table et al.)

低下した。また，Table 中の植物油すべてで計算した $n-6 / n-3$ 比の平均が 4.7 となり，1994 年度の推定 n-6/ n-3 比の 4.7 とちょうど一致した。すなわち，摄取する 植物油の種類を変えることにより $\mathrm{n}-6 / \mathrm{n}-3$ 比を容易に変 化させうることが明らかとなった。

\section{5 脂肪摂取と疾病}

\section{$5 \cdot 1$ 日本における疾病構造の変化}

1952 年以降の日本人の死亡率は Fig. 6 のように推移 し，がんや心疾患が顕著に増加した。また，高血圧，心 疾患をはじめとし，がん，糖尿病，虚血性心疾患の受療 率（Fig. 7）も著しく増加している。これらの疾患は加 齢に関係することから，いわゆる成人病と称して，疾病 予防対策がこれまで進められてきた。厚生省は1996 年 に, これらの成人病の発症は個人の生活習慣と関連が強 いとして，生活習慣病と呼称することとした ${ }^{14)}$ 。今後の 高齢化社会に対応するためには，この生活習慣病の対策 を講ずる必要がある。

\section{$5 \cdot 2$ 摂取脂肪と疾病との関連}

日本における疾病構造の変化は, 脂肪摄取量の著しい 増加と呼応しており，掑取脂肪と疾病との間に何らかの 関係のあることが推測される。脂肪攝取量や脂肪の質の 違いと動脈硬化性疾患発症との関連についてはいうまで もなく，近年ではがんとの関連も明らかとなってきた。 35～57 歳の男性につき, 食事と死亡率の関係を 10 年半 検討した Multiple Risk Factor Intervention Trial (MR FIT) によると，がんによる死亡率は $\alpha$-リノレン酸/リ ノール酸比や $n-3 / n-6$ 比が上昇すると明らかに減少し
Table 3 Effects of Fatty Acid Ratios if Fats are Replaced by Various Oils.

\begin{tabular}{lcc}
\hline & n6/n3 & LA/LNA \\
\hline \multicolumn{1}{c}{1994} & 4.66 & 8.97 \\
\hline Perilla oil & 1.23 & 1.40 \\
Rape seed oil & 3.16 & 4.92 \\
Blended salad oil & 3.53 & 5.61 \\
Blended oil & 4.03 & 6.57 \\
Soybean oil & 4.44 & 7.40 \\
Olive oil & 3.99 & 8.33 \\
Rice bran oil & 4.91 & 10.07 \\
Corn oil & 5.48 & 11.22 \\
Sesame oil & 5.45 & 11.63 \\
Sunflower oil & 6.48 & 13.82 \\
Cotton seed oil & 5.99 & 12.87 \\
Peanut oil & 5.18 & 11.25 \\
Safflower oil & 6.91 & 15.13 \\
Palm kernel oil & 3.77 & 8.08 \\
Palm oil & 4.04 & 8.65 \\
Coconut oil & 3.77 & 8.16 \\
\hline
\end{tabular}

Blended salad oil $=$ Rape seed oil 7 : Soybean oil 3 Blended oil $=$ Rape seed oil 3 : Soybean oil 7 $\mathrm{n} 6 / \mathrm{n} 3=$ All of $\mathrm{n} 6 \& \mathrm{n} 3$ fatty acids LA/LNA $=$ Linoleic acid $/ \alpha$-Linolenic acid $た^{15)}$ 。

Tsuji ら ${ }^{16)}$ は日本における結腸がんの年齢調整別死亡 率と栄養素摂取量の相関を検討したところ, 脂肪搨取量 や脂肪エネルギー比との相関が強いことを 1996 年に発 表した。さらに, 脂肪攝取量, 脂肪エネルギー比, 脂肪 椇取量と食物纎維掑取量の比と結腸がん死亡率との関係 は 2 相性の直線関係があり，それぞれ $50 \mathrm{~g}, 21 \%, 2.9$ 以上で死亡率は急上昇することを示した（Fig. 8)。

日本では, がんを部位別に見ると, 結腸がん, 乳がん の死亡率が増加している。そこで, 今回の脂肪酸撕取量 の推移と結腸がんによる死亡率との関係を検討してみ た。その結果, 先の報告とまったく同様の現象が認めら れ, 脂肪摂取量は約 $51 \mathrm{~g}, \mathrm{~S}$ は約 $14 \mathrm{~g}, \mathrm{M}$ は約 $16 \mathrm{~g}, \mathrm{P}$ は約 $11 \mathrm{~g}, \mathrm{n}-6$ 系 $\mathrm{P}$ は約 $9 \mathrm{~g}, \mathrm{n}-3$ 系 $\mathrm{P}$ は約 $2 \mathrm{~g}$ の㠌取 がターニングポイントとなる 2 相性の回帰直線の関係が 認められた。n-6/n-3 比に関しては明確な関連が認めら れず,ある比率のところで変化することが推察されるが, まだ検討を加える必要があると思われた。また，乳がん と脂肪酸掑取量との関係も検討したところ，ほぼ同様の 結果が得られた ${ }^{17)}$ 。さらに, 原島・辻ら ${ }^{18)}$ は糖尿病と食 物繊維捸取量や他の栄養素摂取量との関係を解析し, 有 病率も死亡率も脂肪摄取量と正相関関係のあることを認 めている。今回の各脂肪酸摂取量と糖尿病死亡率との間 の関係でも，いずれも正相関を示していた ${ }^{19)}$ 。

以上の解析をまとめてみると, 脂肪攝取量や脂肪酸摃 取量があるレベルを越えると各種疾病による死亡率が急 


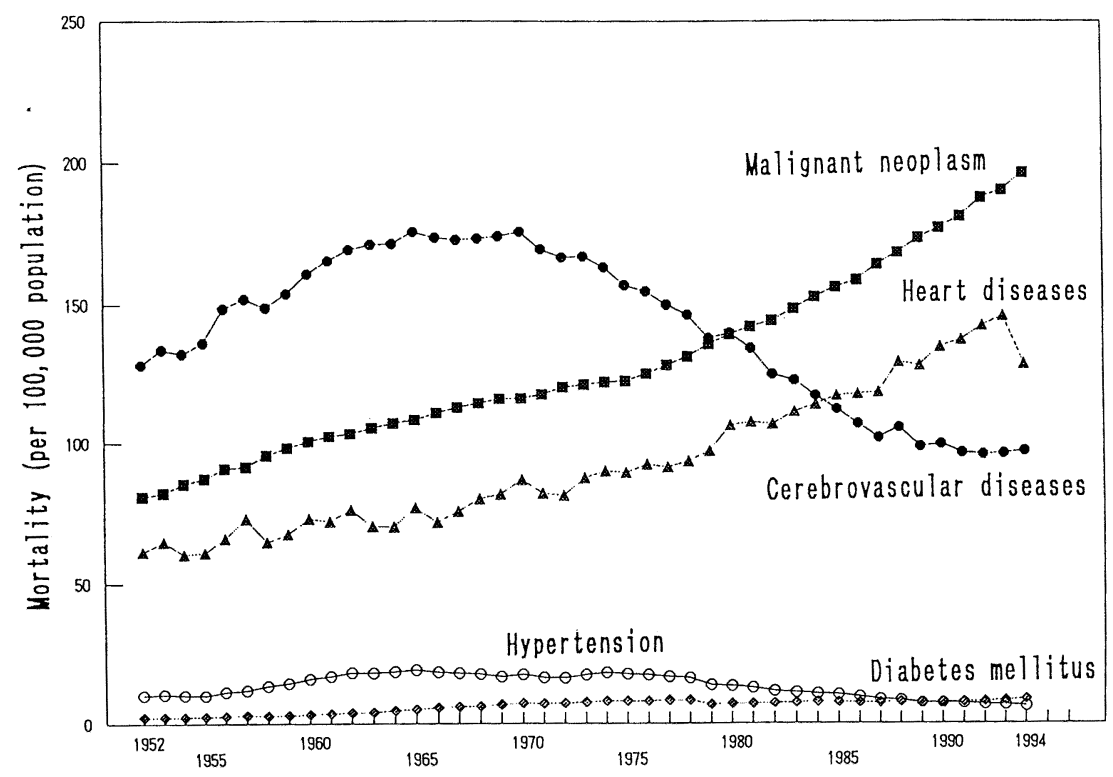

Fig. 6 Changes of Mortality in Japan.

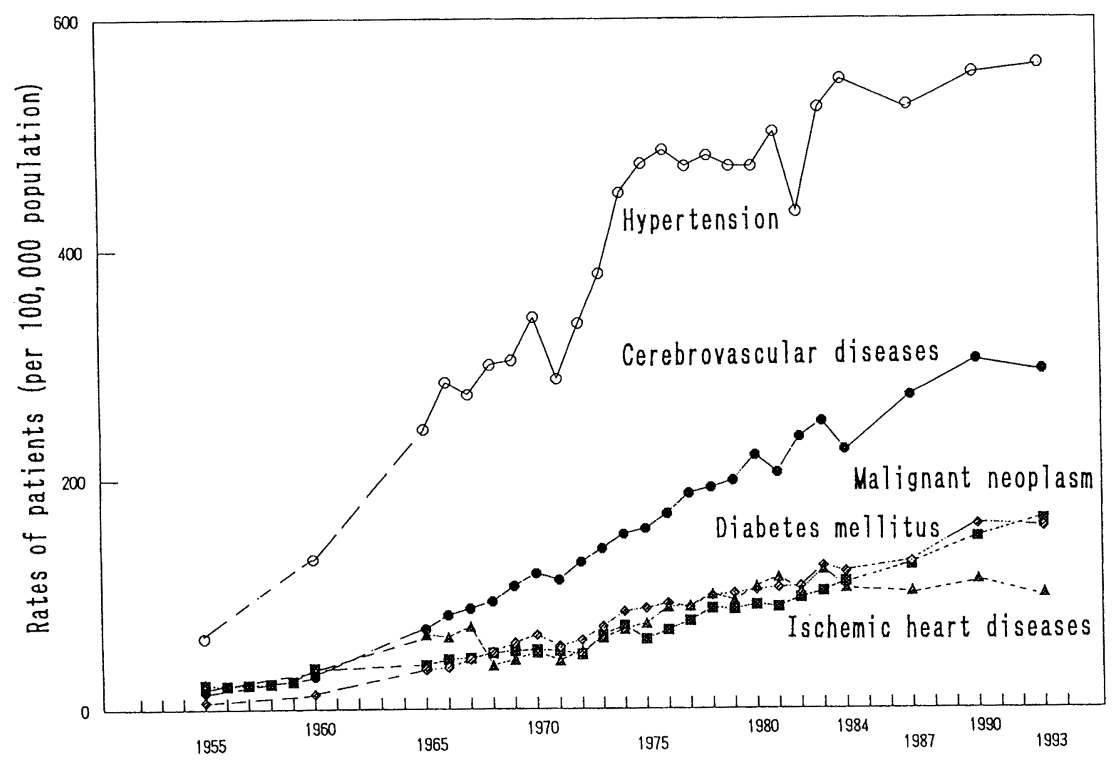

Fig. 7 Trends of Rates of Patients in Japan.

上昇することが明らかで，これが至適䀧取量の上限の一 つの目安を示唆するものと考えられた。

\section{6 日本における脂肪捸取の推奨值}

日本における脂肪摂取の推奨值は, 国が定めてきたこ れまでの栄養所要量をたどることにより理解することが できる。日本における栄養所要量は, 総理府, 科学技術 朾から厚生省へと策定の所管が変遷しながら数回改定さ
れてきたが，それぞれの説明資料では改定当時の背景に も触れている。

\section{$6 \cdot 1$ 脂肪の捸取量}

脂肪摂取の適量値の決定には, エネルギー源の一つと して，古くは国民の食生活の現状に合わせながら国民の 栄養を改善する方針がとられてきた。1954年の日本人 の栄養所要量に関する解説（総理府資源調査会報告）中 では，脂肪の掑取をエネルギー比で $20 \%$ 以上にするこ 


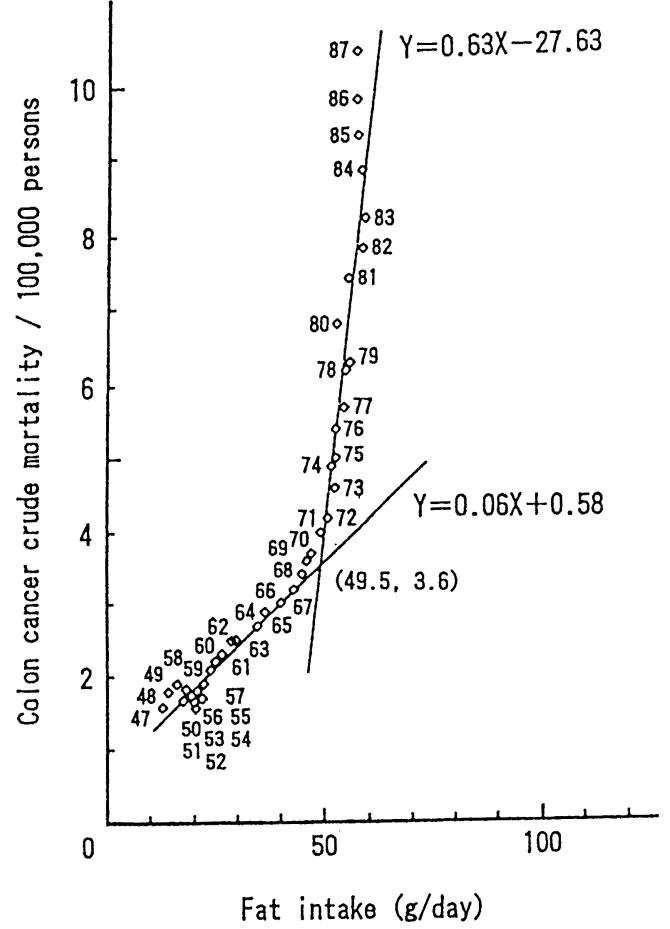

Fig. 8 Regression Lines for the Crude Mortality from Colon Cancer and Fat Intake.

* Numbers show the years. (K. Tsuji et al.)

とが望ましいが，国民の長年の食習慣や経済的事情を考 虑し, 急激に増加するのは困難であるとして, 当面の目 標を平均 1 人 1 日当たり $30 \mathrm{~g}$ (エネルギー比に換算する と $12 \%$ になる）とした。1965 年に厚生省が示した日本 人の栄養所要量で脂肪はエネルギー比で $20 \%$ 程度と示 され，1975 年の改定時まではエネルギーやタンパク質 を中心としながら，国民の栄養状態を改善するために， 脂肪掑取を增加させる方向で進んできた ${ }^{20}$ 。

\section{$6 \cdot 2$ 脂肪の量・質的勧告}

さらにこの 1975 年の改定時には, 量的評価ばかりで なく，質的な勧告を初めて行ったのである。すなわち， $\mathrm{S}$ の多い動物性脂肪と $\mathrm{P}$ の多い植物性油のバランスを とることが大切で, その比率は $1: 2$ を目標とし，少な くとも 1：1より低下させないようにすることが望まし いとされた。というのも，前に述べたように 1955 年頃 から脂肪撕取量は飛躍的に増加し, 動物性脂肪の比重が 大きくなってきたからである。

動脈硬化性疾患発生率と脂肪掑取量との間の正相関か 明らかになるばかりでなく，搷取する油脂の種類によっ ても大きな影響を受け， $\mathrm{S}$ の多い動物性脂肪と $\mathrm{P}$ の多 い植物性油では影響を異にするなど，多くの研究が進展 してきた。このようなことから，量だけではなく，質に
も言及したのであった。

その後, 脂肪掑取, とくに動物性脂肪摄取の增加は乳 がんや大腸がんの発生に関係が深いことも示唆されるよ うになり，1979 年改定時には，脂肪捸取の過剩やそれ から派生する健康上の諸問題の防止のために，脂肪を工 ネルギー所要量とは別に独立して位置づけし，脂肪エネ ルギー比を明確にした。すなわち，日本人に適当と思わ れる脂肪エネルギー比を年齢・性・労作別に，また乳幼 児・妊婦・授乳婦別に設定した ${ }^{21)}$ 。

さらにPとしては，植物油に多いリノール酸， $\alpha-$ リ ノレン酸のみならず，魚類に含まれる $\mathrm{n}-3$ 系 $\mathrm{P}$ のイコ サペンタエン酸やドコサヘキサエン酸が高脂血症の改善 作用だけでなく，血栓症の予防にも有効なことが認めら れるようになった。これを受けて 1984 年の第 3 次改定 では，質では従来動物性脂肪に加えていた魚介類の脂肪 は植物性脂肪（ヤシ油を除く）と同等の価値を持つもの として, 動物性由来（魚類を除く）の脂肪と，植物性お よび魚類由来の脂肪との椇取比率を $1: 2 \sim 1: 1$ の範囲 が望ましいと勧告した。

次いで, 1989 年に示された第 4 次改定栄養所要量で は，質的配虑を新たにし， n-6 系と n-3 系 P のバランス をとることが大切として, 魚類を除く動物性由来の脂肪 と植物性脂肪および魚類由来の脂肪をバランスよく摂取 するようにと勧めた。

1994 年には第 5 次改定栄養所要量22)が発表された。 量的水準については, 従来ど扔り脂肪エネルギー比で示 したが，18歳以上の者については，20歳以上の者と同 様に $25 \%$ を限にしたことは注目に值する。生活活動 強度別や妊娠・授乳期のレベルは従来と同じである。

最も注目されるべきは，「バランス良い㧒取」という 従来の表現から, 脂肪酸の掑取割合について目安の数值 を示したことと, DHA をはじめとする $\mathrm{n}-3$ 系 $\mathrm{P}$ の役割 を強調したことである。すなわち, 動物性, 植物性, 魚 類由来の脂肪, $\mathrm{S}, \mathrm{M}, \mathrm{P}$ および $\mathrm{n}-6$ 系・ $\mathrm{n}-3$ 系 $\mathrm{P}$ の生 体における機能を考虑し望ましい数值として, 動物性： 植物性：魚類由来の脂肪 $=4: 5: 1, \mathrm{~S}: \mathrm{M}: \mathrm{P}=1: 1.5$ $: 1, \mathrm{n}-6$ 系 $\mathrm{P}: \mathrm{n}-3$ 系 $\mathrm{P}=4: 1$ と示した。

脂肪酸に対する関心が高くなっている時代に即応する ためには，バランス良い掑取という表現からもっと具体 的に方向性を示す必要性が高かったのである。今まで脂 肪酸の攝取割合としては， $\mathrm{P} / \mathrm{S}$ 比が使用されていた。 $\mathrm{S}$ および Pの機能や P の必須性はいうまでもないが, 最 近の研究では Mの働きも重要視されるようになってき た。すなわち，Mの代表であるオレイン酸はオリブ油 に多く，オリブ油を使用する地中海食を攝取する地方で は動脈硬化性疾患が少ないことが知られ，血中の HDL コレステロールを低下することなく総コレステロールを 低下することも報告されている23.24)。今日の日本の現状 
Table 4 Recommended Dietary Allowances for the Japanese.

\begin{tabular}{ll}
\hline \multicolumn{2}{c}{ Fat energy ratio $(\%)$} \\
\hline By the age group \\
Infants, younger than 6 months & 45 \\
6 months or older & $30 \sim 40$ \\
$1 \sim 17$ years & $25 \sim 30$ \\
18 years or older & $20 \sim 25$ \\
Pregnant/Lactating women & $20 \sim 30$ \\
\hline
\end{tabular}

Fatty acid intake

SFA : MUFA : PUFA $=3: 4: 3$

n-6 PUFA : n-3 PUFA $=4: 1$

(Ministry of Health and Welfare, 1999)
からは S:M : P の比率は $1.1: 1.3: 1$ であり, S はも ちろん，増え続けている $\mathrm{P}$ の攖取量を抑えるためにも Mの比率を増やすことは大きな意味がある。

動物性, 植物性, 魚類由来の脂肪摂取割合については, 日本人の現状が $4: 5: 1$ であることによっている。

推奨される $n-6 / n-3$ 比については欧米諸国では 4 から 10 であり ${ }^{25)}$ ，母乳での比率も 5 から 10 とされている。 人乳中の含量比などから考えて, 5 以下が自然で至適で ある ${ }^{26)}$ とか，脳や網膜機能のためには 4 10 が必要とも 報告されている27)。これらに対して n-6/n-3 比を 1 また

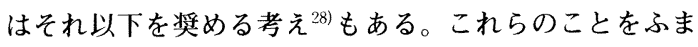
えた上で，日本人の脂肪酸撕取割合の現状は 4 5 とい う報告が多いことから現状を目安として設定されたもの である。本年, 日本人の栄養所要量の第 6 次改定が発表 され，脂肪については妊婦・授乳婦の数值が変わつた他 は量的には変化はなく, 脂肪酸掑取比率は $\mathrm{S}: \mathrm{M}: \mathrm{P}$ を

Table 5 Recommended Dietary Allowances in Several Countries.

\begin{tabular}{|c|c|c|c|c|}
\hline Country & Year & Sex & $\begin{array}{c}\text { Energy } \\
(\mathrm{kcal})\end{array}$ & Fat \\
\hline USA & (1989) & $\begin{array}{c}\mathrm{M} \\
\mathrm{F}\end{array}$ & $\left.\begin{array}{l}2900 \\
2200\end{array}\right]$ & $\mathrm{S} ; 10 \mathrm{E} \% \mathrm{M} ; 10 \mathrm{E} \% \mathrm{P} ; 10 \mathrm{E} \%$ \\
\hline England & (1991) & $\begin{array}{l}\mathrm{M} \\
\mathrm{F}\end{array}$ & $\left.\begin{array}{l}2550 \\
1940^{-}\end{array}\right]$ & {$\left[\begin{array}{rl}\text { with Alcohol : Fat } ; 33 \mathrm{E} \% & \text { Fatty acid ; 30E } \% \\
& \mathrm{~S} ; 10 \mathrm{E} \% \quad \mathrm{M} 12 \mathrm{E} \% \text { P } 6 \mathrm{E} \% \quad \text { LA/LNA } ; 5 \\
\text { No Alcohol } & : \text { Fat } ; 35 \mathrm{E} \% \quad \text { Fatty acid } ; 32.5 \mathrm{E} \% \\
& \mathrm{~S} ; 11 \mathrm{E} \% \quad \mathrm{M} ; 12 \mathrm{E} \% \quad \mathrm{P} ; 6.5 \mathrm{E} \% \text { LA/LNA } ; 5\end{array}\right.$} \\
\hline Italy & (1978) & $\begin{array}{c}M \\
F\end{array}$ & $\begin{array}{l}3000 \\
2160\end{array}$ & $\begin{array}{l}\text { Fat } ; 83 \mathrm{~g}(25 \mathrm{E} \%, \mathrm{LA} ; 2 \sim 6 \mathrm{E} \%) \\
\text { Fat } ; 60 \mathrm{~g}\end{array}$ \\
\hline India & (1989) & $\begin{array}{l}\mathrm{M} \\
\mathrm{F}\end{array}$ & $\left.\begin{array}{l}2875 \\
2225\end{array}\right]$ & Fat $; 20 \mathrm{~g}$ \\
\hline Canada & (1990) & $\begin{array}{l}\mathrm{M} \\
\mathrm{F}\end{array}$ & $\begin{array}{l}3000 \\
2100\end{array}$ & $\begin{array}{ll}\mathrm{n} 3 \mathrm{P} ; 1.6 \mathrm{~g} & \mathrm{n} 6 \mathrm{P} ; 10 \mathrm{~g} \\
\mathrm{n} 3 \mathrm{P} ; 1.2 \mathrm{~g} & \mathrm{n} 6 \mathrm{P} ; 7 \mathrm{~g}\end{array}$ \\
\hline Scandinavia & (1989) & $\begin{array}{l}\mathrm{M} \\
\mathrm{F}\end{array}$ & $\left.\begin{array}{l}2800 \\
2050\end{array}\right]$ & 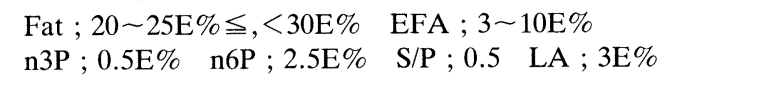 \\
\hline USSR & (1988) & $\begin{array}{l}\mathrm{M} \\
\mathrm{F}\end{array}$ & $\begin{array}{l}3000 \\
2550\end{array}$ & $\begin{array}{l}\text { Fat } ; 110 \mathrm{~g} \\
\text { Fat } ; 93 \mathrm{~g}\end{array}$ \\
\hline Formosa & (1987) & $\begin{array}{c}\mathrm{M} \\
\mathrm{F}\end{array}$ & $\left.\begin{array}{l}2750 \\
2050\end{array}\right]$ & Fat $;<30 \mathrm{E} \%$ \\
\hline China & (1988) & $\begin{array}{c}\mathrm{M} \\
\mathrm{F}\end{array}$ & $\left.\begin{array}{l}3000 \\
2700\end{array}\right]$ & Fat $; 20 \sim 25 \mathrm{E} \%$ \\
\hline Czechoslovakia & (1981) & $\begin{array}{l}\mathrm{M} \\
\mathrm{F}\end{array}$ & $\begin{array}{l}3000 \\
2600\end{array}$ & $\begin{array}{l}\text { Fat } ; 100 \mathrm{~g} \text { LA } ; 8.9 \mathrm{~g} \\
\text { Fat } ; 90 \mathrm{~g} \text { LA } ; 7.7 \mathrm{~g}\end{array}$ \\
\hline Germany & (1991) & $\begin{array}{c}\mathrm{M} \\
\mathrm{F}\end{array}$ & $\left.\begin{array}{l}2600 \\
2200\end{array}\right]$ & $\mathrm{EFA} ; 3.5 \mathrm{E} \%$ \\
\hline Japan & (1994) & $\begin{array}{l}\mathrm{M} \\
\mathrm{F}\end{array}$ & $\left.\begin{array}{l}2550 \\
2000\end{array}\right]$ & $\begin{array}{r}\text { Fat } ; 20 \sim 25 \mathrm{E} \% \text { (Animal }: \text { Vegetable }: \text { Fish }=4: 5: 1, \\
\mathrm{~S}: \mathrm{M}: \mathrm{P}=1: 1.5: 1, \mathrm{n} 6 \mathrm{P}: \mathrm{n} 3 \mathrm{P}=4: 1)\end{array}$ \\
\hline
\end{tabular}

S : Saturated fatty acid, M : Monounsaturated fatty acid,

$\mathrm{P}:$ Polyunsaturated fatty acid,

n6: n-6 Polyunsaturated fatty acid,

n3: n-3 Polyunsaturated fatty acid

LA : Linoleic acid, LNA : $\alpha$-Linolenic acid

EFA : Essential fatty acid, E\% : Energy \% 
Table 6 Recommendations of Fat and Fatty Acid.

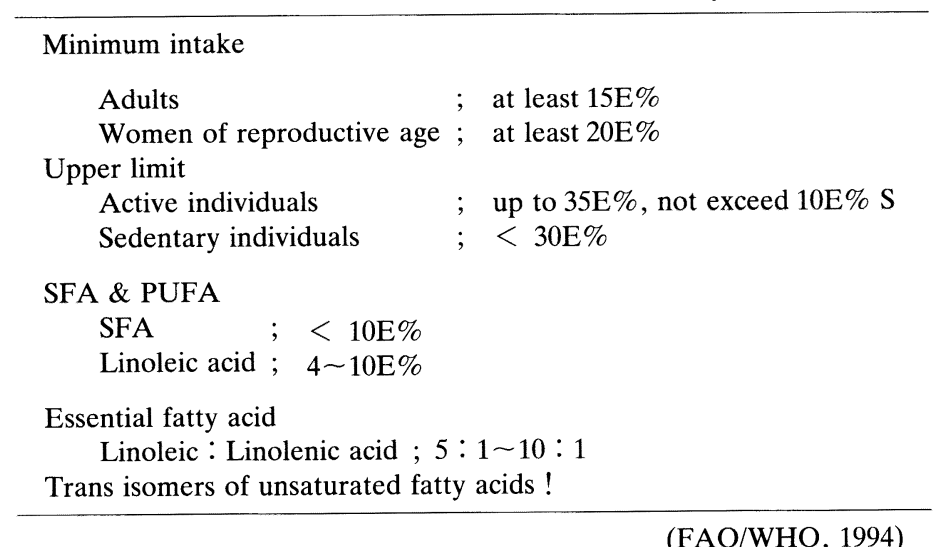

Table 7 Dietary Guidelines for Americans

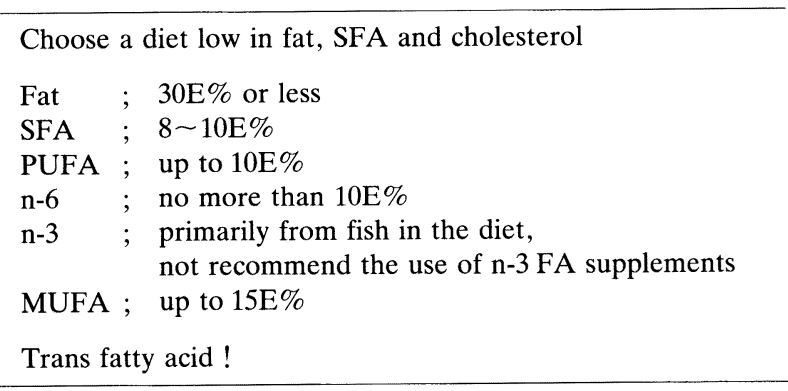

(AHA, 1996)

$3: 4: 3, \mathrm{n}-6$ 系 $\mathrm{P}$ と $\mathrm{n}-3$ 系 $\mathrm{P}$ を $4: 1$ 程度と推奖した (Table 4)。

\section{7 諸外国の脂肪推奨量}

各国で推奨されている所要量につき，脂肪に関してま とめたものを Table 5 に示す。脂肪の絶対量, 脂肪エネ ルギー比, 必須脂肪酸のエネルギー比, S P M P P エネ ルギー比, $\mathrm{n}-6 \cdot \mathrm{n}-3$ 系 $\mathrm{P}$ の量またはエネルギー比, リ ノール酸/ $\alpha$-リノレン酸比と様々の表現法で推奖されて いる。

かつて, FAO/WHO は一般成人の必須脂肪酸量は最 低 3 エネルギー\%と勧告した。1994 年に FAO/WHO ${ }^{29)}$ は Table 6 のように，アメリカ心臓学会は健康なアメリ 力人の食事指針 ${ }^{30)}$ のなかで, Table 7 のように脂肪摂取 量を推奖している。

また，最近の情報によれば，国際脂肪酸・脂質学会 (ISSFAL) のワークショップ (USA, April 1999) で, 成人の適正摂取量としてリノール酸・ $\alpha$-リノレン酸・ $\mathrm{EPA}+\mathrm{DHA}$ をそれぞ $2 \cdot 1 \cdot 0.3$ エネルギー\%とし たとのことである。先の推計掑取量からすれば，日本人 はEPA や DHA は魚食の関係もあって十分㪸取してい
る。しかし， $\alpha$-リノレン酸を現状よりは少し増やし， リノール酸摂取を減少させる必要がありそうである。 $\alpha$-リノレン酸含有量の多い油脂の需要に合うような供 給形態を考える必要もあろう。

\section{8 おわりに}

健康を維持するために日本人の脂肪酸の椇取量や各脂 肪酸の搨取比率について, 至適な值はどのくらいだろう か。これだけの資料と解析で速断するわけにはいかない が，推奨值が示されるのも近いと思われる。

しかし，国が定める栄養所要量は，あくまでも国民が 健康を保持・増進し, 適正に成長・発有し, さらに生活 習慣病の予防のために各栄養素をどれくらいとったら良 いかを示すものであり, 第 6 次改定では過剩摂取への対 応も考虑されたとのことである。これらの值は日常の食 生活に活かせるものでなくてはならない。しかも普遍性, 妥当性の高いものである必要がある。また, 動物実験の 成績をそのまま演繹してよいというものでもない。さら に, 食品の供給状況も大いに関係してくる。

これまでの脂肪椇取の変遷から, $\mathrm{n}-6$ 系 $\mathrm{P}$ であるリ ノール酸の掑取量が増え各種疾患発症の要因となってい 
る可能性は大きい。とすれば，リノール酸搷取量を減ら すような努力が必要となる。一方， $\alpha$-リノレン酸を中 心とする $\mathrm{n}-3$ 系 $\mathrm{P}$ の有用性も明らかであり掑取を増や す必要があるが，先にも述べたようにこれら n-3 系脂肪 酸も過剩摂取になれば各種疾患による死亡率などが急上 昇することを考え合わせると，いくらでも撕取してよい というわけでは決してなく, 撕取量の上限値というもの がありそうである。

今までのところでは, 疫学的調查にしろ各研究者によ る報告にしろ，䀧取する脂肪・脂肪酸量を測定したり推 測しているわけで，動物実験のように投与した結果が明 確に出現したということではない。とくに日本人での成 績は非常に少ない。ヒト，とくに日本人での科学的かつ 確実で正しい成績の集積が期待されるところである。

(受付：1999 年 5 月 6 日, 受理：1999 年 7 月 27 日)

\section{文献}

1）金田尚志 (監訳)：人間の栄養における食用油脂の 役割 FAO/WHO 合同専門家委員会報告，医柬薬 出版 (1980).

2）菅野道廣：油脂の栄養一いかに考えるべきか，原 一郎監修 島崎弘幸・町田芳章編集, 油脂の栄養 と疾病, 幸書房 (1990) p.150.

3) 芦田 淳: 食生活と栄養 食生活論, 同文書院 (1991) p.19.

4) 健康 - 栄養情報研究会監修 中原澄男著, 公衆栄 養と栄養指導, 第一出版 (1992) p.80.

5) 厚生省保健医療局地域保健 - 健康増進栄養課生活 習慣病対策室監修：平成 9 年版国民栄養の現状, 第一出版 (1999).

6）東京都衛生局：幼児期からの健康づくりのために 平成 6 年幼児健康栄養調查結果, (1995) p.20.

7) 石永正隆, 松田久美子, 田茂井盛子, 向井加織, 鬼頭 誠, 日本栄養·食糧学会誌, 44, 437 (1991).

8) 辻 悦子, 油化学, 37, 810 (1988).

9) 吉田 昭, 油化学, 40, 467 (1991).
10) 辻 啓介, 油化学, 40, 783 (1991).

11）平原文子, 脂質栄養学, 4, 73 (1995).

12）辻 悦子, 脂質栄養学, 7, 56 (1998).

13）科学技術庁資源調査会報告第 112 号：四訂日本食 品標準成分表のフォローアップに関する調査報告 II一日本食品脂溶性成分表 (脂肪酸, コレステロー ル, ビタミン E)-(1989).

14）公衆衛生審議会：生活習慣に着目した疾病対策の 基本的方向性について (意見具申) (1996).

15) T.A. Dolecek, PSEBM, 200, 177 (1992).

16) K. Tsuji, E. Harashima, Y. Nakagawa, G. Urata, M. Shirataka, Biomedical and Environmental Sciences, 9, 223 (1996).

17) 辻 悦子：脂肪酸の摂取バランスと疾病 日本栄 養・食糧学会監修, 五十嵐脩・菅野道廣責任編集 脂肪酸栄養の現代的視点, 光生館 (1998) p.186.

18）原島恵美子, 辻 啓介, 中川靖枝, 浦田郡平, 日 本家政学会誌，45，1079 (1994).

19）辻 悦子, 日本栄養·食糧学会誌, 50, 462 (1997).

20）厚生省公衆衛生局栄養課監修 国民栄養振興会編, 昭和 50 年改定日本人の栄養所要量と解説, 第一出 版 (1975) p.42.

21）厚生省公衆衛生局栄養課編，昭和 54 年改定日本人 の栄養所要量, 第一出版 (1979) p.44, p.51.

22) 厚生省保健医療局健康増進栄養課監修: 第五次改 定日本人の栄養所要量, 第一出版 (1994) p.56.

23) F.H. Mattson, S.M. Grundy, J. Lipid Res., 26, 194 (1985).

24) S.M. Grundy, N. Engl. J. Med., 314, 745 (1986).

25) 板倉弘重, 臨床栄養, 85, 162 (1994).

26) P. Budowski, MA. Crawford, Proc. Nutr. Soc., 44, 221 (1985).

27) M. Neuringer, W.E. Connor, Nutr. Rev., 44, 285 (1986).

28）奥山治美, 脂質栄養学, 1, 20 (1992).

29) FAO and WHO : Fats and oils in human nutritionReport of a joint expert consultation, (1994) p.3.

30) AHA MedicallScientific Statement : Circulation, 94, 1795 (1996). 


\title{
[総説］＼cjkstart肥満：エネルギー調節メカニズムと食事
}

\author{
中 村 丁 次 \\ 聖マリアンナ医科大学病院栄養部 \\ （テ216-8511＼cjkstart神奈川県川崎市宮前区菅生 2-16-1）
}

ヒトのエネルギー代謝の調節機能を検討し，肥満者では調節機能障害が存在することが明らかになった。特に 肥満者には, 安静時代謝や食後の熱産生の低下が見られ，エネルギー代謝のセットポイントのずれが肥満の成因 として考えられた。このようなエネルギー代謝障害に食事や栄養素がどの様に関与しているのかも検討した。そ の結果，脂肪の過剩摂取や朝食の欠食，夕食・夜食の過剩㠌取が体脂肪の貯蔵を助長することも解った。

(連絡者：中村丁次) Vol.48, No.10, 997 (1999)

\section{[総説] \\ 健康の維持と油脂の至適摂取量： 脂肪酸の摂取バランスを中心に}

\author{
辻 悦子 \\ 川崎医療福祉大学医療技術学部健康体育学科
}

（７ 701-0193 岡山県倉敷市松島 288）

油脂の摂取は健康維持のために重要であるが, 油脂中の構成脂肪酸により, 油脂の栄養学的機能は異なる。こ のためバランス良い摃取が望まれ，日本人の栄養所要量では脂肪の量のみならず脂肪酸の質についても望ましい 㠌取比率が推奨されている。

健康維持のための至適な油脂摂取量を考えるために, 日本人の今までの脂肪摂取量や栄養所要量を検討し, 脂 肪酸摂取量や脂肪酸摂取比率を算出した。

1946 年の脂肪摂取量は $14.7 \mathrm{~g}$, 脂肪エネルギー比は $7.0 \%$ であったが, 1997 年には脂肪摂取量は $59.3 \mathrm{~g}$, 油脂 類の摂取量は $17.0 \mathrm{~g}$ であった。これらの脂肪摂取量の増加は植物油のみならず動物性脂肪の著しい増加に依るも のであった。

脂肪や脂肪酸摄取量と疾病との関連を検討したところ, それぞれある㠌取レベルを越えると各種疾病による死 亡率が急上昇することが明らかで，これが至適掑取量の上限の一つの目安を示唆するものと考えられた。

(連絡者：辻 悦子) Vol.48, No.10, 1005 (1999) 